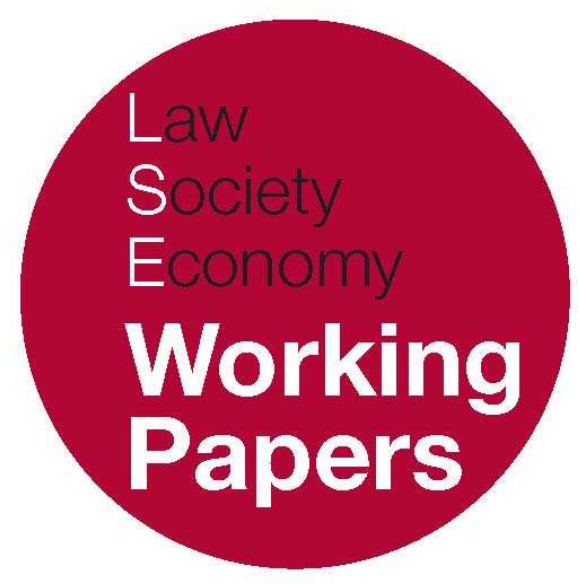

\title{
Pluralism in Global Risk Regulation: The Dispute over GMOs and Trade
}

\author{
Nico Krisch \\ LSE Law, Society and Economy Working Papers 17/2009 \\ London School of Economics and Political Science \\ Law Department \\ This paper can be downloaded without charge from LSE Law, Society and Economy Working \\ Papers at: www.lse.ac.uk/collections/law/wps/wps.htm and the Social Sciences Research \\ Network electronic library at: http://ssrn.com/abstract=1491608. \\ (C) Nico Krisch. Users may download and/or print one copy to facilitate their private study or \\ for non-commercial research. Users may not engage in further distribution of this material or \\ use it for any profit-making activities or any other form of commercial gain.
}




\title{
Pluralism in Global Risk Regulation: The Dispute over GMOs and Trade
}

\author{
Nico Krisch ${ }^{*}$
}

\begin{abstract}
Debates about the construction of postnational law and global governance are usually dominated by a constitutionalist prism, by the hope to establish order through principled hierarchies on a domestic model. Yet what we see emerging is quite different: it is a pluralist order in which the different parts (of domestic, regional, and global origin) are not linked by overarching legal rules, but interact in a largely political fashion. This paper traces the structure of pluralism in a central area of global governance, the regime complex around trade, food safety and the environment, using the example of the dispute over trade with genetically modified organisms (GMOs). It analyses the different institutions and their modes of interaction in this area, and it shows how their competing authority claims relate to broader claims by various collectives striving for control in the construction of global governance. The paper also seeks to shed light on the common charge that pluralist orders create instability. The analysis of the GMO dispute does not confirm this view; it reveals limits to what global risk regulation can achieve in the face of highly politicised conflict, but it also shows significant cooperation successes. Moreover, it suggests that the limits of cooperation are due less to institutional than to societal structures and that a pluralist order, by leaving issues of principle open, may provide a safety valve for issues of high salience, thus avoiding frictions a constitutionalist order might produce.
\end{abstract}

\footnotetext{
*Hertie School of Governance, Berlin; krisch@hertie-school.org. This paper was written while I was a visiting fellow at the LSE Law Department, and I gratefully acknowledge the institutional support of the Department. I am also grateful to Andrew Lang, Anne Thies, Greg Shaffer and Nicolas Lamp for comments, suggestions and help. A revised version of this paper will appear in N. Krisch, Beyond Constitutionalism: The Pluralist Structure of Postnational Law (Oxford: Oxford University Press, 2010).
} 


\section{INTRODUCTION}

The construction of postnational law is fraught with anxieties. As the boundary between domestic and international politics and law has become ever more blurred, we are still lacking structural paradigms for the new, more integrated space. These paradigms should be able to respond both to the increasingly direct impact of transnational and global institutions and to our normative convictions about how public power (on whatever level) should be organised and hedged in. This is a major challenge, and the most obvious move to alleviate our anxieties is to have recourse to something we know: to use paradigms from domestic law and politics and extend them into the postnational sphere. Constitutionalism is a particularly popular candidate, and it has typically come with the hope for creating a principled, unified framework for global governance on the model of domestic order.

Yet what we see emerging in global governance is quite the opposite: it is a pluralist order in which the different parts, of domestic, regional, and global origin are not linked by overarching legal rules, but interact in a largely political fashion. I have tried to illustrate this in a previous piece with the example of the European human rights regime, and I have tried to sketch a normative case for such a pluralist order in another. ${ }^{1}$ In the present paper, I use the example of global risk regulation around the dispute over trade with genetically modified organisms (GMOs) to take this exploration further.

The example of the GMO dispute should help us to shed light on a number of key issues for an account of the postnational order. One of them is the breadth of the pluralist phenomenon: the complex regime of risk regulation that connects GMO issues with food safety and environmental matters is yet another example of how pervasive pluralist structures are in central areas of global governance. Second, the example highlights some of the factors behind, and benefits of, pluralist orders, namely as regards channels of input from different collectives competing for control of global regulation. A third important theme is that of stability: here, the GMO dispute appears as a particularly hard case, as an example of 'when cooperation fails', and it seems to confirm fears that pluralism will have disruptive effects. Yet, as shall become clear, this may not necessarily be the case: there are many points of convergence around GMOs, and much evidence of successful cooperation in the broader regime complex on sanitary and phytosanitary regulation. Moreover, it is more than doubtful that those failures of cooperation we can observe are in fact caused by the pluralism of governance arrangements - quite the contrary.

\footnotetext{
${ }^{1}$ N. Krisch, 'The Open Architecture of European Human Rights Law', (2008) 71 Modern Law Review 183; N. Krisch, 'The Case for Pluralism in Postnational Law' (LSE Working Paper no. 12/2009) at http://ssrn.com/abstract=1418707; a revised version is forthcoming in G. de Búrca and J.H.H. Weiler (eds), The Worlds of European Constitutionalism (Cambridge: Cambridge University Press, 2010).

2 M.A. Pollack and G.C. Shaffer, When Cooperation Fails: The International Law and Politics of Genetically Modified Foods (Oxford: Oxford University Press, 2009).
} 
The paper proceeds in four steps. It first sketches the contours of the substantive disputes over GMOs and their institutional expression in different sites of governance. It then demonstrates the legal pluralism at work here, in both a horizontal and a vertical dimension. It goes on to analyse the competition between different visions of the right polity to determine the issues at stake, and how it has shaped the pluralism of the governance structure. In a last part, the paper considers the extent to which this pluralism has been of a disruptive or a stabilising nature - the extent to which it may have hindered or helped cooperation in this area.

\section{THE GMO DISPUTE}

\section{The Substantive Disagreement}

In the GMO dispute, two fundamentally opposed approaches confront each other, and both respond to deeply held convictions about risk, nature, and scientific progress. ${ }^{3}$ On the one hand, the 'permissive' approach that is today dominant in the United States sees restrictions on the production, sale, and use of foodstuffs as justified only when there are scientifically proven risks for human health, the environment, or other important goods. Absent such proof, the production, sale, and use of food and feed is free, and since for many products that contain GMOs or have been produced on the basis of GMOs risk assessments have not revealed ascertainably higher risks than for other products, restrictions are not warranted under this approach.

On the other hand, the 'precautionary' approach that is largely favoured in Europe (although with significant differences amongst countries ${ }^{4}$ ) emphasizes the scientific uncertainty that even thorough risk assessments leave and insists that in situations of uncertainty and potentially serious risks, one should err on the side of caution. Since the consequences for public health and the environment of products containing or based on GMOs cannot be fully determined - in part because of the short time that has so far been available for testing and in part because testing is usually limited to small contexts and does not extend to entire ecosystems - the precautionary approach tends to restrict the production, sale, and use of such products significantly. Regulatory approvals of the production and sale of such products have accordingly been very limited in Europe; for several years, EU institutions even operated a de facto moratorium on new applications.

\footnotetext{
${ }^{3}$ I can only provide a brief sketch of a huge issue here. On the two general approaches, see D. Vogel, 'The Politics of Risk Regulation in Europe and the United States' (2003) 3 Yearbook of European Environmental Law 1; Pollack and Shaffer, n 2 above, ch 2. For a cautionary note on the differences between the US and Europe, see J.B. Wiener and M.D. Rogers, 'Comparing Precaution in the United States and Europe', (2002) 5 Journal of Risk Research 317.

${ }^{4}$ On the contestation of food safety issues in Europe itself, see C. Ansell and D. Vogel (eds), What's the Beef? The Contested Governance of European Food Safety (Cambridge, Mass: MIT Press, 2006).
} 
On a more general level, the competing approaches reflect divergent attitudes towards risk in scientific progress and in particular to alterations of nature and its potential consequences. But in the case of the EU, the more cautious approach also stems from recent experiences in the area of food safety, in particular the BSE scandal, as well as concerns about the effect of a shift towards GMO food and feed for the agricultural landscape. In that, it may also be connected with a desire to shield the relatively small European agricultural businesses from the pressures for stronger industrialization that GMO agriculture and competition with largescale American farms would bring. But even though on both sides of the Atlantic, regulatory approaches are certainly influenced by economic interests and are also due to institutional structures and path-dependence, ${ }^{5}$ they have far deeper social roots. In Europe, a majority of citizens has consistently declared its opposition to the use of GMOs, while in the US, majorities or pluralities favour their genetic engineering for particular purposes or more broadly for the commercial use of GM products. ${ }^{6}$

These two approaches, usually coexisting peacefully, clash over questions of global trade. US exports of agricultural products containing or based on GMOs to Europe are severely limited by stringent EU rules, and exports to developing countries are often hampered because of the wish of these countries to export agricultural products to Europe, which is more difficult with GMOs in the food chain. Accordingly, the contest between the two approaches takes place mostly in trade-related institutions and involves many more players than just the US and the EU.

\section{THE INSTITUTIONAL CONTEST}

Regulatory cooperation on GMO matters was initially rather effective, taking place in bodies of a largely technical character, most importantly within the OECD and the Codex Alimentarius Commission, a standard-setting organisation in the area of food safety set up by FAO and the WHO in 1962.7 It ran into difficulties, though, when in the mid-1990s, the issue became increasingly politicised in Europe, positions became more entrenched, and disagreement could no longer be treated as merely technical. ${ }^{8}$ By that time, however, regulatory efforts, especially those of the Codex, had become embedded in the new WTO framework, especially through the Agreement on the Application of Sanitary and Phytosanitary Measures, the SPS Agreement - a treaty that, unlike most other texts of the Uruguay Round, had been accorded relatively low priority and was negotiated

\footnotetext{
5 The importance of this latter point is highlighted by Pollack and Shaffer, $\mathrm{n} 2$ above, 72-73.

6 cf D.W. Drezner, All Politics is Global: Explaining International Regulatory Regimes (Princeton: Princeton University Press, 2007), 156-158; Pollack and Shaffer, n 2 above, 73-75. For recent data on Europe, see also 'Attitudes of European Citizens towards the Environment' (Special Eurobarometer 295, March 2008), 65 at http://ec.europa.eu/public_opinion/archives/ebs/ebs_295_en.pdf.

7 On the Codex Alimentarius Commission (CAC), see WHO/FAO, Understanding the Codex Alimentarius (2005) at http://www.fao.org/docrep/008/y7867e/y7867e00.htm.

8 On the trajectory of regulatory cooperation on GMOs, see Pollack and Shaffer, n 2 above, ch 2.
} 
quite speedily, largely by technical experts and without much fundamental controversy. ${ }^{9}$ The SPS Agreement grants the Codex Alimentarius Commission, among a few other standard-setting bodies, an elevated role in that its standards enjoy particular weight in determining whether national measures are in conformity with the agreement. States can establish more exacting conditions than those contained in Codex standards, but only if they can provide a justification based upon a scientific risk assessment of the products in question. ${ }^{10}$

This emphasis on science, ${ }^{11}$ initially agreeable to all sides, soon came to haunt the Europeans. Their increasingly precautionary approach seemed to be in tension with this emphasis, and in the late 1990s, it came under scrutiny in the WTO framework, especially in the Beef Hormones case. The EU had banned the import and sale of meat derived from hormonally treated farm animals, thus limiting the export prospects of (especially) American meat producers significantly, and it had done so well beyond the restrictions provided for in Codex standards. The argument that this was justified as a matter of precaution was, however, not accepted; the WTO Appellate Body saw those measures as lacking a sufficient basis in scientific assessments of the risks the hormones actually posed..$^{12}$

This finding did not automatically doom the EU's GMO measures - after all, the Appellate Body has at times left considerable scope for national regulation in public health and environmental matters, and it has indicated that a precautionary approach may find wider application than just for the provisional measures which are explicitly admitted in the SPS Agreement. ${ }^{13}$ Some commentators thus believe a good case can be made for the conformity of European GMO policies with the Agreement. ${ }^{14}$ Yet on a number of other occasions, the Appellate Body has rejected arguments of precaution and found restrictive measures to violate WTO law. ${ }^{15}$

${ }^{9}$ Drezner, n 6 above, 161-163; T. Büthe, "The Globalization of Health and Safety Standards: Delegation of Regulatory Authority in the SPS Agreement of the 1994 Agreement Establishing the World Trade Organization' (Winter 2008) 71 Law and Contemporary Problems 219, 238-255; G. Skogstad, 'The WTO and Food Safety Regulatory Policy Innovation in the European Union' (2001) 39 Journal of Common Market Studies 485, 492-494.

${ }^{10}$ SPS Agreement, art 3 at www.wto.org/english/tratop_e/sps_e/spsagr_e.htm. See also J. Scott, The WTO Agreement on Sanitary and Phytosanitary Measures (Oxford: Oxford University Press, 2007), ch 7.

11 On the dominant role of science in the SPS Agreement and WTO decisions, see J. Peel, 'Risk Regulation Under the WTO SPS Agreement: Science as an International Normative Yardstick?' (Jean Monnet Working Paper no. 02/04, 2004) at www.jeanmonnetprogram.org/papers/04/040201.html.

12 EC Measures Concerning Meat and Meat Products [16 January 1998] WTO Appellate Body WT/DS26/AB/R and WT/DS48/AB/R (hereinafter 'BeefHormones').

13 See only R. Howse, 'The WHO/WTO Study on Trade and Public Health: A Critical Assessment' (2004) 24 Risk, Analysis 501.

${ }^{14} \mathrm{eg} \mathrm{R}$. Howse and P.C. Mavroidis, 'Europe's Evolving Regulatory Strategy for GMOs - The Issue of Consistency with WTO Law: Of Kine and Brine' (2000) 24 Fordham International Law Journal 317; A.A. Ostrovsky, 'The New Codex Alimentarius Commission Standards for Food Created with Modern Biotechnology: Implications for the EC GMO Framework's Compliance with the SPS Agreement' (2004) 25 Michigan Journal of International Law 813.

15 Precautionary considerations are explicitly allowed only with respect to provisional measures in situations of insufficient scientific evidence; see SPS Agreement, n 10 above, art 5.7. For the cases, see Beef Hormones, n 12 above; Australia - Measures Affecting Importation of Salmon [20 October 1998] WTO Appellate Body WT/DS18/AB/R; Japan - Measures Affecting Agricultural Products [22 February 1999] WTO Appellate Body WT/DS76/AB/R; Japan - Measures Affecting the Importation of Apples [26 November 2003] WTO Appellate Body WT/DS245/AB/R. For a good overview of the first three cases, see D.G. Victor, 
Quite understandably then, Europeans came to see the SPS jurisprudence as likely to pose a challenge to their regulatory approach vis-à-vis GM products, and they looked for strategies to change or destabilise it.

A crucial part of these strategies was the Biosafety Protocol. ${ }^{16}$ Negotiated in the framework of the Convention on Biodiversity (CBD) and thus a part of the Rio Process on environmental protection, it represented an attempt at establishing a counterweight to WTO rules. The route via the CBD appeared promising because of its greater membership compared to the WTO and the resulting stronger role of developing countries, many of which were sceptical towards GMO foods and feeds. Moreover, as the US was not a party to the CBD, it could take part in the negotiations only as an observer. In the end, this did not relegate it to a secondary role - the US played a major part in the process, largely as a member of the 'Miami Group' of countries with an interest in the export of GMO products, and it managed to significantly limit the EU's ability to draft a treaty along the lines of its regulatory vision. Still, the eventual Protocol places emphasis on the 'Advance Informed Agreement' of countries importing GMO products that are to be released into the environment ${ }^{17}$ and, besides its requirement of a scientific risk assessment as a basis for the importing decision, the Protocol makes several references to precautionary measures. ${ }^{18}$ It states in particular that a lack of scientific certainty shall not prevent a party from taking measures to avoid or minimize potential adverse effects of GMOs to be imported as food or feed. ${ }^{19}$ It is thus relatively close to European approaches to GMOs, ${ }^{20}$ and commentators believed that as an 'international standard', it could potentially have an impact on decision-making under the SPS Agreement similar to that of the Codex Alimentarius standards. ${ }^{21}$ Yet the ultimate relationship with WTO law is left unclear in the Protocol itself. After long negotiations, the Biosafety Protocol addresses the issue in two contradictory clauses in the preamble: one emphasizes that the Protocol is not intended to change rights and obligations under other agreements, while the other insists that this proviso is not meant to subordinate the Protocol to other agreements. ${ }^{22}$

'The Sanitary and Phytosanitary Agreement of the World Trade Organization: An Assessment After Five Years' (2000) 32 NYU Journal of International Law and Politics 865, 895-913.

16 Cartagena Protocol on Biosafety (adopted 29 January 2000) at www.cbd.int/biosafety [hereinafter 'Biosafety Protocol']. On the protocol and its negotiation, see C. Bail, R. Falkner, and H. Marquard (eds), The Cartagena Protocol on Biosafety: Reconciling Trade in Biotechnology with Environment and Development (London: Earthscan, 2002); M. Böckenförde, Grüne Gentechnik und Welthandel: Das Biosafety-Protokoll und seine Auswirkungen auf das Regime der WTO (Heidelberg: Springer, 2004), 118-240.

${ }^{17}$ Biosafety Protocol, n 16 above, art 7.

${ }^{18}$ See especially ibid, Preamble and art 1.

19 ibid, art 11 , para 8.

${ }^{20}$ R. Falkner, 'Regulating Biotech Trade: the Cartagena Protocol on Biosafety' (2000) 76 International Affairs 299, 301-302, 313; Böckenförde, n 16 above, 140-144.

${ }^{21}$ See Howse and Mavroidis, n 14 above, 354-370; see also L. Boisson de Chazournes and M.M. Mbengue, 'GMOs and Trade: Issues at Stake in the EC Biotech Dispute' (2004) Review of European Community and International Environmental Law 13, 289, 297-303; Böckenförde, n 16 above, 333-336.

22 See S. Safrin, 'Treaties in Collision? The Biosafety Protocol and the World Trade Organization Agreements' (2002) American Journal of International Law 96, 606, 614-628; Falkner, n 20 above, 309-310. 
The negotiations on the Biosafety Protocol operated in the shadow of the US threat to initiate WTO proceedings if the EU failed to relent on the issue, as did efforts of the EU to reform its approval system for GMO products. Limited as they were, these hardly assuaged the American side, and attempts at creating greater regulatory convergence - in both the OECD and Codex - also floundered because of the distance between the positions. ${ }^{23}$ US efforts to negotiate the issue within the WTO context failed as Europeans preferred the CBD forum. ${ }^{24}$ Against the background of such entrenched viewpoints, the US eventually acted upon their threat and brought a case before the Dispute Settlement Body in 2003.25

The Panel took more than three years to decide and finally presented a report running to more than a thousand pages - even by WTO standards a massive document. ${ }^{26}$ It ruled in favour of the US, but because of the limited scope of the proceedings and the narrow basis of the Panel's reasoning, the report has come to be seen as leaving most crucial issues open. ${ }^{27}$ Because of the way the US had framed their application, the Panel did not make a pronouncement on the EU's regulatory system, but limited itself to the de facto moratorium on approvals and the safeguard bans of a number of individual EU member states. It was clear on the substantive incompatibility of the latter with the SPS Agreement for lack of a rational relation with the risk assessments available. But its stance on the former was more circumscribed: it found the EU's moratorium to be in violation of the Agreement, but only because it represented an 'undue delay' in deciding on applications. The Panel notably avoided any pronouncement on whether the EU position had a sufficient scientific basis. ${ }^{28}$ In its consideration of member state measures, it pointed out that there would be room for precautionary considerations if a risk assessment indicated 'uncertainties or constraints' in its evaluation. ${ }^{29}$

Though favouring the US in the result, this leaves open the possibility that the European regulation of GMOs may be in (or could relatively easily be brought into) conformity with SPS rules. ${ }^{30}$ Despite a number of principled statements on the interpretation of the SPS Agreement, ${ }^{31}$ the Panel's report as a whole has a rather circumscribed character, avoiding broad statements wherever possible and founding its eventual conclusions on the narrowest grounds available. It brackets

\footnotetext{
23 Pollack and Shaffer, n 2 above, 58-68, 142-145, 168-174, 237-245.

${ }^{24}$ Falkner, n 20 above, 305.

25 Pollack and Shaffer, n 2 above, 179-182; Drezner, n 6 above, 165-170.

${ }^{26}$ European Communities - Measures Affecting the Approval and Marketing of Biotech Products [29 September 2006] WTO Panel WT/DS291/R (hereinafter 'Biotech').

${ }^{27}$ Pollack and Shaffer, $\mathrm{n} 2$ above, ch 5.

${ }^{28}$ See the summary of the findings in Biotech, $\mathrm{n} 26$ above at [8.2]-[8.10].

$29 \mathrm{ibid}$ at [7.3065], [7.3244]-[7.3245].

${ }^{30}$ Pollack and Shaffer, n 2 above, 196-197.

31 Some of these have been the subject of pronounced critique; see eg J. Peel, 'A GMO by Any Other Name...Might be an SPS Risk!: Implications of Expanding the Scope of the WTO Sanitary and Phytosanitary Measures Agreement' (2006) 17(5) European Journal of International Law 1009; M.A. Young, 'The WTO's Use of Relevant Rules of International Law: An Analysis of the Biotech Case', (2007) 56 International and Comparative Law Quarterly 907; R.L. Howse and H. Horn, 'European Communities Measures Affecting the Approval and Marketing of Biotech Products' (2009) 8 World Trade Revien 49.
} 
the key areas of disagreement between the parties, just as they have been left out by regulatory bodies for want of common ground. The dispute thus continues. ${ }^{32}$ To be sure, the EU claims to have ended its moratorium: since 2004, it has begun to process (and sometimes approve) applications, though in the US view, still at too slow a pace and in too small a number. Efforts by the European Commission to remove the national safeguard bans have so far - despite the clear findings of violation by the Panel in this respect and parallel assessments by the European Food Safety Authority - met with sustained resistance amongst member states and in the Council of Ministers. Given the strength of adverse public opinion in Europe and the concomitant risk of further antagonism, the US has also suspended its proceedings to gain authority for retaliatory sanctions in response to the continued non-compliance by EU member states, though only provisionally, as it points out, to give the EU the 'opportunity to demonstrate meaningful progress. ${ }^{3}$

\section{THE GMO DISPUTE IN A PLURALIST ORDER}

So far, I have told the story of the GMO dispute largely as one of regulatory conflict, adjudication, and non-compliance, situated mainly between two actors and channelled through a variety of institutions. Yet it is also a story of an ever more visible legal pluralism and its driving force - the competition of different collectives for ultimate law-making authority.

\section{Horizontal Pluralism in the Global Food SaFety Regime Complex}

The pluralism on show in this example has two dimensions, one vertical and the other horizontal. I have already touched upon the latter in the description of the creation of the Biosafety Protocol and its ambiguous rules on its relationship with WTO law. But is this an instance of pluralism or perhaps simply another case of conflicting treaty obligations, to be solved according to the classical rules of international law?

In the eyes of the Panel in the Biotech case, it is certainly the latter. The Panel framed the issue, understandably, from the perspective of WTO law and mainly asked whether and how, under standard international law rules, the provisions of the Biosafety Protocol mattered to the interpretation of the SPS Agreement. Using the Vienna Convention on the Law of Treaties (VCLT), it came to the conclusion that it did not have to be taken into account as long as some parties to the dispute were not parties to the Protocol. ${ }^{34}$ This conclusion appeared to differ in tone

\footnotetext{
32 See Pollack and Shaffer, n 2 above, ch 6.

33 cf Pollack and Shaffer, n 2 above, 227.

34 Biotech, n 26 above at [7.75]. For an insightful discussion, see Young, n 31 above.
} 
(though perhaps not in result) from previous uses of other international agreements by the W'TO Appellate Body which had emphasised that WTO law should not be read "in clinical isolation from public international law". 35 But it is unexceptional given the wording of the VCLT, which provides for an interpretive effect of "any relevant rules of international law applicable in the relations between the parties"; 36 in the case of the Biosafety Protocol, it was simply not 'applicable' between the parties as not all of them were bound by it. The Panel also offered some further reasoning for why this was an adequate solution:

Indeed, it is not apparent why a sovereign State would agree to a mandatory rule of treaty interpretation which could have as a consequence that the interpretation of a treaty to which that State is a party is affected by other rules of international law which that State has decided not to accept. ${ }^{37}$

On the basis of state voluntarism, this is a plausible consideration. In this particular case, it left little space for using the Biosafety Protocol: the Protocol certainly could not serve as a mandatory tool to interpret the SPS Agreement; its only role could be that of helping to illuminate the 'ordinary meaning' of the terms of the Agreement. ${ }^{38}$ This accorded the Protocol a role akin to that of dictionaries sometimes useful, but only taken into account if the Panel so wished or considered appropriate. Ultimately, though, the Panel "did not find it necessary or appropriate to rely on these particular provisions [of the Biosafety Protocol] in interpreting the WTO agreements at issue in this dispute". 39

This approach is in line with the typical response of many international lawyers to what they perceive as an increasing 'fragmentation' of the international legal order. ${ }^{40}$ Expressed through a proliferation of treaties and regimes, institutions, and courts, this fragmentation not only appears as the flipside of the growth in strength and breadth of international law, but also seems to pose a threat to its unity and coherence. After a period of unease and irritation, however, most international lawyers found they could address the resulting problems by applying the classical rules governing treaty interpretation and conflicting

\footnotetext{
35 United States - Standards of Reformulated and Conventional Gasoline [20 May 1996] WTO Appellate Body WT/DS2/AB/R at [16]. See also Howse and Horn, n 31 above, 60-62, and the survey in International Law Commission, Fragmentation of International Law: Difficulties arising from the Diversification and Expansion of International Law (Report of the Study Group, finalized by Martti Koskenniemi, 13 April 2006) UN Doc A/CN.4/L.682, paras 165-171, 443-450.

${ }^{36}$ Vienna Convention on the Law of Treaties (adopted 22 May 1969, entered into force 27 January 1980) UNTS 1155, 331, Art 31 para 3 (c).

37 Biotech, $\mathrm{n} 26$ above at [7.71].

38 ibid at [7.92]-[7.95].

39 ibid at [7.95].

40 From what is by now a vast literature on the topic, see eg M. Koskenniemi and P. Leino, 'Fragmentation of International Law. Postmodern Anxieties?' (2002) 15 Leiden Journal of International Law 553; M. Craven, 'Unity, Diversity and the Fragmentation of International Law' (2003) 14 Finnish Yearbook of International 3.
} 
obligations. ${ }^{41}$ This path was taken most prominently by the United Nations' International Law Commission (ILC), which spelled out in much detail how the rules of VCLT on interpretation and norm conflicts, such as lex specialis, lex posterior, etc., applied to the multiplicity of rules governing many issue areas in global governance..$^{42}$ In the view of this eminent body, there was little new under the sun. Conflicts between obligations had always existed and were the logical result of an order of sovereigns:

Because of the spontaneous, decentralized and unhierarchical nature of international law-making - law-making by custom and by treaty - lawyers have always had to deal with heterogeneous materials at different levels of generality and with different normative force. ${ }^{43}$

If today the focus had shifted from inter-sovereign to inter-regime conflicts, international law, with its ideals of 'system' and 'systemic integration', retained the moderating impetus that had characterised it all along and could provide, or develop, collision rules to avoid incoherence and friction. ${ }^{44}$

Yet the harmonising effects of an international law thus understood have limits, and the report of the ILC's study group, as finalised by its chairman, Martti Koskenniemi, acknowledged as much: many normative conflicts, expressions of diverging preferences, and values rather than merely technical mistakes "require a legislative, not a legal-technical response". 45 The development of interpretation and conflict rules can hardly deliver as much, and in their current form, they also have intrinsic limits. Those rules focus on inconsistent norms between the same states: it is then that the interpretive tools of the Vienna Convention, or rules on lex specialis and lex posterior, have some bite. They do not, however, resolve conflicts between obligations that are owed to different parties. The formal solution here is clear: the addressee of the obligations has to fulfill both, and if this is impossible, it will incur responsibility - including financial liability - for falling foul of at least one of them.

If this may be a sensible solution in a contractual framework, it becomes more problematic if one emphasises the legislative aspects of the rules in question. ${ }^{46}$ The unresolved parallelism of individual obligations, mitigated by potential monetary compensation, then turns into a largely unmediated

${ }^{41}$ See eg P.M. Dupuy, 'L'unité de l'ordre juridique international' (2003) 297 Recueil des cours de l'Académie du droit international 9. With a particular focus on the WTO, see eg J. Pauwelyn, Conflict of Norms in Public International Law (Cambridge: Cambridge University Press, 2003), chs 5-7.

42 See International Law Commission, 'Conclusions of the work of the Study Group on the Fragmentation of International Law' (Report on the work of its fifty-eighth session, 2006), UN Doc A/61/10, paras 241-251; International Law Commission, n 35 above.

${ }^{43}$ International Law Commission, n 35 above, para 486.

${ }^{44} \mathrm{Ibid}$, paras 487, 489, 493; International Law Commission, n 42 above, nos 1, 4.

45 International Law Commission, n 35 above, para 484.

46 A similar focus can be found in N. Matz, Wege zur Koordinierung välkerrechtlicher Verträge (Heidelberg: Springer, 2005), ch 7-9. See also the mention of the 'legislative ethos' of many multilateral efforts in International Law Commission, n 35 above, para 471. 
competition of regulatory, legislative programmes. And this is far from a rare occurrence: wherever regimes have a great number of parties, identity of membership - the precondition for the operation of collision rules - is likely to be elusive. In the WTO context, apart perhaps from the UN Charter, hardly any agreement will have all WTO members as parties. Beyond this, collision rules typically conceived as giving expression to some underlying will of the parties will often be doomed to failure. ${ }^{47} \mathrm{~A}$ rival regime will often have its main purpose in counteracting a previous set of rules; amending those rules in the ordinary procedure is typically too cumbersome and will often require unanimity. As we have seen, the GMO case is a prime example of such a counteracting strategy, and the Biosafety Protocol's own collision rules reflect best the unavailability of a 'state will' to resolve its tension with the SPS Agreement. ${ }^{48}$ Little could be deduced from preambular clauses such as the following:

Recognizing that trade and environment agreements should be mutually supportive with a view to achieving sustainable development,

Emphasizing that this Protocol shall not be interpreted as implying a change in the rights and obligations of a Party under any existing international agreements,

Understanding that the above recital is not intended to subordinate this Protocol to other international agreements... ${ }^{49}$

The relationship between the agreements hangs in the balance here, and the classical tools of international law soon run out. ${ }^{50}$ Just like the Biosafety Protocol, WTO law claims for itself the right to define its status vis-à-vis other regimes: we have seen this in the Panel Report in Biotech, but it is also on display in the decisions of the Appellate Body which refer quite frequently to other international legal rules, but do not necessarily accord them much interpretive weight. ${ }^{51}$

The result is a regime complex with a multiplicity of interacting sites of governance, each of which insists on determining its relationship with the outside. ${ }^{52}$ This is reminiscent of an account based upon systems theory, ${ }^{53}$ and it shows how thin the framework of international law has become - how little

\footnotetext{
${ }^{47}$ See also Matz, n 46 above, 336-339.

${ }^{48}$ For another example, see C.B. Graber, 'The New UNESCO Convention on Cultural Diversity: A Counterbalance to the WTO?' (2006) 9 Journal of International Economic Law 553; H. Ruiz-Fabri, 'Jeux dans la Dragmentation: La Convention sur la Promotion et la Protection de la Diversité des Expressions Culturelles' (2007) 111 Revue Générale de Droit International Public 43.

${ }^{49}$ Biosafety Protocol, n 16 above, Preamble.

${ }^{50}$ See $\mathrm{n} 22$ above.

51 See eg Measures Affecting the Importation of Certain Poultry Products [13 July 1998] WTO Appellate Body WT/DS69/AB/R, EC at [83]. See also the International Law Commission, n 35 above, para 445.

52 On the concept of a regime complex, see K. Raustiala and D.G. Victor, 'The Regime Complex for Plant Genetic Resources' (2004) 58 International Organization 277, 295-305; on the notion of 'sites of governance', see F. Snyder, 'Governing Economic Globalisation: Global Legal Pluralism and European Law' (1999) 5 European Law Journal 334.

${ }^{53}$ For such an account, see A. Fischer-Lescano and G. Teubner, Regime-Kollisionen: Zur Fragmentierung des globalen Rechts (Frankfurt a.M.: Suhrkamp, 2006).
} 
impact its integrating, 'systemic' impetus now has. This all the more as the contestation I have described is not only a contestation about the application of particular rules, but as we shall see below ${ }^{54}$ one about the structure and scope of the polity - a contestation about fundamentals, expressed in a pluralist legal order.

\section{Vertical Pluralism: National LaW, European Law, WTO LaW}

The picture is similar in the vertical dimension - between WTO law and regional or national legal systems. This relationship is generally characterised by a distance in principle - and is one that is typically greater than is the case for other norms of international law. This is particularly noticeable in the United States: when approving the WTO Agreements, the Congress emphatically excluded any form of reliance on them in the courts, providing that "[n]o provision of any of the Uruguay Round Agreements ... that is inconsistent with any law of the United States shall have effect" and that "[n]o person other than the United States ... may challenge ... any action or inaction by any department, agency, or other instrumentality of the United States ... on the ground that such action or inaction is inconsistent with such agreement". ${ }^{55}$

Even if international agreements are today often denied self-executing character by the US upon ratification, this denial in the case of WTO law is exceptionally clear and pronounced and has also led to a particular hesitancy amongst the courts to use WTO law, even as an interpretative device. ${ }^{56}$

In our context, of greater interest is the position of the European Union - the receiving end of WTO disciplines in this case. Politically, the Council of the EU positioned itself in a way similar to the US Congress, stating that the WTO Agreements are "not susceptible to being directly invoked in Community or Member State courts". ${ }^{57}$ But this was only part of the preamble of the Council's decision to conclude the agreements, and it certainly has not hindered ample speculation about the status of WTO law in EU law, both within and outside the courts. This speculation was fuelled by the ECJ's position on the status of the GATT 1947. As we have seen in the discussion of Security Council sanctions, the ECJ has traditionally been relatively open to international law, recognising its direct effect in the EC legal order from early on. ${ }^{58}$ The GAT'T was an outlier from the beginning: already in the 1972 International Fruit Company decision, the Court found it not to be "capable of conferring on citizens of the Community rights which they can invoke before the courts". This was chiefly due to the great flexibility of the GATT's provisions, the possibilities of derogation, and the power

\footnotetext{
54 See below, IV.

55 United States Uruguay Round Agreement Act, 19 U.S.C. \$3512, paras (a) (1) and (c) (1).

56 See A. Davies, 'Connecting or Compartmentalizing the WTO and United States Legal Systems? The Role of the Charming Betsy Canon’ (2007) 10 Journal of International Economic Law 117.

57 European Council Decision 94/800 [22 December 1994]; [23 December 1994] OJL 336/1, concerning the conclusion on behalf of the European Community, as regards matters within its competence, of the agreements reached in the Uruguay Round multilateral negotiations (1986-1994).

58 ibid, ch 4.
} 
of unilateral withdrawal from its obligations. ${ }^{59}$ The creation of the W'TO raised doubts about this stance, primarily because the 'great flexibility' was to be significantly reduced by the advent of the new, far more powerful dispute settlement mechanism. Yet hopes for a change in direction were thwarted in successive steps: in 1999, in Portugal v Council, the ECJ rejected the idea that the new institutional setup of the WTO made a difference to the status of the GATT in EU law; ${ }^{60}$ in later decisions, it also denied direct effect to other WTO agreements, such as TRIPS and the TBT Agreement; ${ }^{61}$ it held that the existence of clear rulings by the W'TO Dispute Settlement Body did not change the situation; 62 and it rejected claims of damages based on non-compliance with such rulings. ${ }^{63}$ Holding expressly that:

[a]s regards ... the W'TO agreements, it is settled case-law that, given their nature and structure, those agreements are not in principle among the rules in the light of which the Court is to review the legality of measures adopted by the Community institutions, ${ }^{64}$

the ECJ firmly closed the door on all attempts to reduce the distance that exists between EU law and WTO law as a matter of principle.

The Court, however, did recognise exceptions to this strict separation, notably in two circumstances: when EU law makes 'clear reference' to WTO law or when it seeks to transpose a particular part of it into the EU legal order. In these cases, an EU act can be invalidated if found incompatible with W'TO law. ${ }^{65}$ Moreover, the Court frequently uses the tool of treaty-consistent interpretation to read EU law in the light of international law and also of WTO law. Using these mechanisms, the European courts have drawn upon W'TO law in hundreds of cases and established a thick jurisprudence on it. ${ }^{66}$ As I will discuss in some greater detail below, the separation in principle has thus not hindered an engagement in practice.

What is clear, though, is that it alters the spirit of engagement. The EC Treaty's clear statement that international "[a]greements ... shall be binding on the institutions of the Community and on Member States" ${ }^{\prime 67}$ and the ECJ's deduction

59 International Fruit Company [12 December 1972] ECJ C 21-24/72; [1972] ECR 1219.

60 Portugal v Council [23 November 1999] ECJ C-149/96; [1999] ECR I-8395 at [36]-[47].

${ }^{61}$ Dior [14 December 2000] ECJ C-300/98 and C-392/98 at [42]-[44]; Omega Air [12 March 2002] ECJ C$27 / 00$ and $\mathrm{C}-122 / 00$ at [85]-[97].

${ }^{62}$ FLAMM and Fedon [9 September 2008] ECJ C-120/06 and C-121/06 at [125]-[133].

63 ibid at [120]-[124].

64 ibid at [111].

65 See eg Portugal v Council, n 60 above at [49]; see also P.J. Kuijper and M. Bronckers, 'WTO Law in the European Court of Justice' (2005) 42 Common Market Law Review 1313, 1323-1328.

66 F. Snyder, 'The Gatekeepers: The European Courts and WTO Law' (2003) 40 Common Market Law Review 313; M. Bronckers, 'From "Direct Effect" to "Muted Dialogue": Recent Developments in the European Courts' Case Law on the WTO and Beyond' (2008) 11 Journal of International Economic Law 885.

67 Treaty Establishing the European Community (as amended by the Treaty of Amsterdam), (signed 25 March 1957, entered into force 1 January 1958), art 300(7). 
that "those agreements have primacy over secondary Community legislation"68 seemed to imply an unconditional subjection of most EU law, a hierarchy in favour of international legal rules, and a tight connection between the two legal orders. The ECJ's stance towards WTO law effects a shift towards a more subtle form of interaction, one in which the Court enjoys far greater flexibility. In this setting, international rules can no longer be directly invoked by private parties, and they rarely allow challenges to the validity of EU legislation. Yet the two exceptions sketched above and the tool of treaty-consistent interpretation grant the courts sufficient leeway to use WTO law when they see fit. For example, they have reviewed EU anti-dumping legislation on the basis of WTO rules ${ }^{69}$, interpreted the EC Customs Code in line with the WTO Agreement on Rules of Origin $^{70}$, and used the TRIPS Agreement to construe national trademark law. ${ }^{71}$ Yet in other areas, the ECJ has stood aside. This is especially so in cases with high salience: for example, on the highly-politicised issues of the EU's banana market ${ }^{72}$ and its ban on the import of hormonally-treated meat ${ }^{73}$, the Court simply referred to its general line and refused to consider the respective WTO rulings.

One consequence of this stance is obviously a stronger role of the political institutions in the EU. The domestic impact of the WTO Agreements now depends upon them to a much larger extent than in the case of automatic direct effect, and this also allows them to deny it - an option that was specifically contemplated by the ECJ. One of the central considerations of the Court in Portugal $v$ Council was the preservation of the freedom of the political organs in dealing with the EU's trading partners. Political options, the ECJ argued, would be unduly restricted if, through the operation of direct effect, the political organs could no longer refuse compliance with WTO rulings and seek a negotiated solution for an issue. ${ }^{74}$ This consideration was, of course, bolstered by the fact that other major parties, such as the US, had not provided for direct effect either ${ }^{75}$. Unilaterally renouncing the option of non-compliance would have seemed to weaken the EU's hand in international trade disputes considerably.

Another reason for insisting on the distance between EU and WTO law was probably the depth and precision of the latter's impact. ${ }^{76}$ The GMO case has provided an example for how the SPS Agreement structures domestic policy choices, but WTO law reaches out into many other issue areas. The resulting impact is broad, but because of the indeterminacy and openness of the agreements, it would normally have left domestic courts - even in the case of

\footnotetext{
${ }^{68}$ See eg IATA [10 January 200]\} ECJ C-344/04 at [35].

${ }^{69}$ eg Petrotub and Republica v Council [9 January 2003] ECJ C-76/00 P.

70 Thomson Multimedia and Vestel France [8 March 2007] ECJ C-447/05 and C-448/05 at [29]-[30].

71 Anheuser Busch v Budvar [16 November 2004] ECJ C-245/02.

72 OGT Fruchthandelsgesellschaft [2 May 2001] ECJ C-307/99 at [24]-[31]; FIAMM, n 62 above.

73 Biret International [30 September 2003] ECJ C-93/02 P at [51]-[65]; see also A. Thies, 'Biret and Beyond: The Status of WTO Rulings in EC Law', (2004) 41 Common Market Law Review 1661.

74 Portugal, n 60 above at [40], [46].

75 Portugal, n 60 above at [43].

76 Snyder, n 66 above, 333; Bronckers, n 66 above, 887.
} 
direct effect - a considerable freedom of interpretation and space for the determination of potential forms of compliance. With the increasing concretisation of the rules through an evermore active dispute settlement mechanism, however, this freedom has been heavily curtailed: indeterminacy no longer provides the buffer between the different layers of law that it had provided before. It is understandable, therefore, that the ECJ sought to reclaim some of the EU's autonomy from an evermore tightly judicialised WTO legal order.

Such an account is all the more plausible in this case as the other two areas in which the ECJ has distanced EU law from international law are likewise characterised by a high degree of institutionalised concretisation. This is obvious in the case of the UN Security Council: in Kadi, the Court insisted on procedural protections in the face of a determination of obligations by the Security Council that went so far as to prescribe detailed modalities of the treatment of individually designated persons..$^{77}$ The other area is that of the law of the sea: here, the ECJ ruled in the Intertanko case - decided only three months before Kadi - that the UN Convention on the Law of the Sea (UNCLOS) operated exclusively in the intergovernmental realm, did not create individual rights, and was, as a result, not directly applicable in the EU legal order. ${ }^{78}$ UNCLOS, like the WTO Agreements, has often been heralded as an example of the increasing legalisation - and especially judicialisation - of international affairs: the International Tribunal for the Law of the Sea, even though it does not at present attract a great number of cases, certainly represents an important element in the move towards dispute settlement by permanent judicial institutions. ${ }^{79}$ The ECJ's response to this move is to distance EU law more effectively. This may appear as a step backward, but it may also be seen as trying to reestablish the marge de manoeuvre that courts had enjoyed in the older, more imprecise global legal order.

\section{A PLURALISM OF COMPETING COLLECTIVES}

This pluralism - which also includes that within Europe ${ }^{80}$ - is not only a legal, technical affair, but is also based on intense social contestation about the locus of authority and the right collective for decision-making on matters of food safety and the environment. Such contestation is at the heart of the normative argument for a pluralist order ${ }^{81}$; here we can observe more specifically how the two phenomena relate to each other in a concrete case.

\footnotetext{
77 Kadi and Al Barakaat [3 September 2008] ECJ C-402/05 P \& 415/05 P.

78 Intertanko [3 June 2008] ECJ C-308/06 at [64]-[65].

79 On the general trend, see eg J. Goldstein, et al (eds), Legalization and World Politics (Cambridge, Mass.: MIT Press, 2001); Société française pour le droit international (ed), La Juridictionnalisation du Droit International (Paris: Pedone, 2003).

${ }^{80}$ See N. MacCormick, 'Beyond the Sovereign State' (1993) 56 Modern Law Review 1; J.H.H. Weiler and M. Wind (eds), European Constitutionalism Beyond the State (Cambridge: Cambridge University Press, 2003).

${ }^{81}$ Krisch, 'The Case for Pluralism', n 1 above.
} 
The contestation about the right collective is most clearly on display in the competition between the SPS Agreement and the Biosafety Protocol for leadership on the issue of GMOs. As mentioned before, the Protocol was an attempt to establish a counterweight to WTO rules, and it was also driven by a desire to rebalance participation in international rule-making - by a wish to make it more inclusive. This may seem counterintuitive, given that the WTO and the Biosafety Protocol (as of May 2009) both have 153 parties. ${ }^{82}$ It becomes more graspable when we look at the number of countries participating in the negotiations: in the Uruguay Round that led to the creation of the W'TO, overall participation reached 123 countries, not even thirty of which were actively involved in the discussions on the SPS Agreement. ${ }^{83}$ Negotiations on the Biosafety Protocol were open to all 175 states that had joined the Biodiversity Convention by early 1999,84 plus a number of observers (sometimes, as in the case of the US, very active ones).

Sheer numbers, however, hardly reflect all the imbalances. One such imbalance concerned the paradigms of negotiation, which in the case of the WTO, largely followed the logic of trade, as trade officials were typically at the helm of negotiations, although on some issues - including SPS negotiations - ministries of agriculture were equally involved. The Biosafety Protocol, in contrast, because it was part of the Rio process, was largely driven by officials from environmental ministries who shared quite a different worldview. ${ }^{85}$ Yet more importantly, the negotiations on the Protocol were relatively strongly influenced by developing countries gathered in the powerful 'Like-Minded Group'. Many of them had difficulties establishing domestic rules on GMO matters, often for lack of expertise and capacity, and they thus had a particular interest in harmonised - and relatively strong - regulation. ${ }^{86}$ The Uruguay Round and the negotiations on the SPS Agreement were to a much greater extent dominated by OECD countries, especially by the US and the EU. 87

In its submissions in the Biotech case, the EU relied heavily on the argument of greater inclusiveness. It used it in a general way to question the appropriateness of the WTO as a forum for deciding on GMO issues, stating that:

it is not the function of the WTO Agreement to allow one group of countries to impose its values on another group. Nor is it the purpose of the WTO Agreement to trump the other relevant rules of international law which permit

\footnotetext{
82 As of 19 May 2009; see www.wto.org/english/thewto e/whatis e/tif e/org6 e.htm; www.cbd.int/biosafety/signinglist.shtml.

83 See www.wto.org/english/thewto_e/whatis_e/tif_e/fact4_e.htm; Büthe, n 9 above, 241.

84 See www.cbd.int/convention/parties/list/.

85 Pollack and Shaffer, n 2 above, 135-136, 157; see also Büthe, n 9 above, 241-242, 252, on the SPS negotiations.

86 Böckenförde, n 16 above, 140-142.

87 See generally J.H. Barton, J.L. Goldstein, T.E. Josling, and R.H. Steinberg, The Evolution of the Trade Regime: Politics, Law, and Economics of the GATT and the WTO (Princeton: Princeton University Press, 2006), 62-67; on the SPS negotiations, see Büthe, n 9 above, 244-245.
} 
- or even require - a prudent and precautionary approach. There is a serious question as to whether the WTO is the appropriate international forum for resolving all the GMO issues that the Complainants have raised in these cases. ${ }^{88}$

More specifically, the argument about the right collective for rule-making on the issue found reflection in the EU position on the role of other international agreements in the proceedings, and in particular in the interpretation of WTO law by the Panel. In the view of the EU,

the issues faced by the Panel have to be taken in their broader context. That context includes other relevant international instruments, which reflect the view of the international community as to the appropriate way to proceed on decisionmaking in relation to GMOs and GM products. The European Communities submits that a failure by the Panel to have regard to this broader context will risk undermining the legitimacy of the WTO system. The Panel should therefore not accede to the Complainants' arguments that this case may be decided in 'clinical isolation' from the rules of public international law more generally. .9

For the EU, it was thus the 'international community', rather than a particular fraction of it, that was called upon to determine the issue, and its views could be gauged better by considering the entirety of global regulatory approaches, including the Biosafety Protocol, even if the complainants were not parties to it.

Yet the invocation of the international community is not the sole, and perhaps not even the decisive, element of the EU position: for as becomes clear from the beginning of the first quote, the EU also insists on the freedom of states from imposition by others - a classical sovereignty theme. This is better reflected in a further statement:

it cannot be right that the Complainants should be allowed to impose their approach on the European Communities, or indeed on any other countries, and to do so through the WTO. Even less so at a time when countries around the world are still trying to clarify the balance between risks and benefits. ${ }^{90}$

How those two aspects - sovereignty and international community - relate is not immediately clear. We may understand them as resisting the idea that the SPS

\footnotetext{
${ }^{88}$ European Communities, First Written Submission in EC - Measures Affecting the Approval and Marketing of Biotech Products (17 May 2004), para 10 at

http://trade.ec.europa.eu/doclib/docs/2004/june/tradoc_117687.pdf.

${ }^{89}$ European Communities, Second Written Submission in EC - Measures Affecting the Approval and Marketing of Biotech Products (19 July 20040, para 8 at

http://trade.ec.europa.eu/doclib/docs/2005/february/tradoc_121552.pdf, (emphasis added).

${ }^{90}$ European Communities, First Written Submission, n 88 above, para 2.
} 
Agreement disposed of the issue of GMOs and as insisting that the issue should be determined either by each state for itself or by a broader international community, but not by the group of states represented in the WTO or by its Dispute Settlement Body.

As we have seen above, the WTO Panel disagreed and approached the issue from the narrower and more formal angle of the SPS Agreement alone. For the Panel, too, this was a consequence of a principled stance in which collective should have the final say on the issue. I have already quoted the passage in which the Panel pointed out that the EU's broader approach could hardly be reconciled with state sovereignty: in its view, a state could only be affected by those obligations it had agreed to undertake. ${ }^{91}$ This reflects a standard state-voluntarist position, although it is less clear how useful it is as a guide for the work of the Dispute Settlement Body. After all, the DSB's task is not only that of restating what states have already agreed to, but also - as with all judicial bodies - of the active, progressive development of those commitments. The reference to consent as an expression of state sovereignty, backward-looking as it is, hardly helps to shed light on what norms and whose views should guide this creative, forwardlooking work. The result of the Panel's rejection of external guidance may in any case be seen as turning the emphasis on sovereignty on its head. It opens up greater space for a transnational body - the Panel itself - to fill the gaps in the WTO Agreements, thus creating precisely the risk to states' freedom from external imposition the Europeans had warned against.

These ambiguities around the meaning of sovereignty, and especially the EU position on it, lead us into another debate about the locus of authority in which the pluralist legal structure is embedded. This debate centres on the idea of 'food sovereignty', a term typically understood as 'the right of peoples and sovereign states to democratically determine their own agricultural and food policies'. ${ }^{92}$ The notion has found strong resonance especially in developing countries as an attempt at reclaiming decision-making power over the production and importation of food and at keeping the influence of international rules and markets at bay. Originating in the sphere of NGOs such as the Via Campesina international peasant movement, ${ }^{93}$ it has inspired numerous civil society groups ${ }^{94}$ and has entered the vocabulary of intergovernmental fora as well. ${ }^{55}$ Moreover, it has found

\footnotetext{
91 See text at $\mathrm{n} 37$ above.

92 International Assessment of Agricultural Knowledge, Science and Technology for Development (IAASTD), Global Summary for Decision-Makers (2008), 15 at

www.agassessment.org/docs/IAASTD_GLOBAL_SDM_JAN_2008.pdf. See also the definition in the Nyéléni Declaration of the Forum for Food Sovereignty at

www.foodsovereignty.org/public/new_attached/49_Declaration_of_Nyeleni.pdf ('Food sovereignty is the right of peoples to healthy and culturally appropriate food produced through ecologically sound and sustainable methods, and their right to define their own food and agriculture systems').

93 See http://viacampesina.org/main_en/index.php.

94 See eg The International Planning Committee Food Sovereignty at

http://www.foodsovereignty.org/new/.

95 See IAASTD, n 92 above.
} 
legislative reflection in Venezuela and has been included in the new constitution of Ecuador. ${ }^{96}$

Beyond that immediate impact, the term provides a link to a host of normative claims about sites of governance on food. Within the EU, for example, the contestation around GMOs has triggered a variety of initiatives for a greater local impact on the extent of cultivation of GM crops. Based upon an Austrian initiative, hundreds of European municipalities and regions have formed a network of 'GMO-free regions', rejecting the cultivation of GM crops on their territories. ${ }^{97}$ As evidenced by its 2008 conference on 'Food and Democracy', a central goal of this campaign is to re-establish the possibility for local or national democratic determination of GMO cultivation and sale, and it is clearly directed against European (and global) rule-making on the issue. Some regions' efforts in this direction have openly clashed with EU law: Upper Austria (Oberösterreich), for example, saw its GMO ban rejected by the European Commission, and then took the case to the courts, but lost in both the European Court of First Instance and the ECJ. ${ }^{98}$ Otherwise, however, as we have seen above, Commission efforts to remove national safeguard bans have so far largely failed because of the degree of resistance from member states, and calls for renationalising decision-making rights on this matter have become louder. ${ }^{99}$ They are likely to resonate with significant parts of the population: in a 2005 European survey on biotechnology, 32 percent of respondents said they wanted the governance of science and technology to be based primarily on moral and ethical considerations rather than on scientific evidence. Additionally, 24 percent wanted the general public, not experts, to have the main influence on decision-making. ${ }^{100}$ These may be minorities - after all, 59 percent of respondents favoured decision-making by experts on the basis of scientific evidence - but they are sizeable enough to sustain resistance to a delegation of powers detached from local and national democratic influence. In any event, with the greater salience of the issue, approval ratings of the European regulation of biotechnology have declined, while those of national regulation are on the increase. ${ }^{101}$

The greater politicisation of the cultivation and trade of GM products has thus removed the issue from the realm of the technical and has placed the

\footnotetext{
96 On Colombia, see art 13 of the 2008 Constitution at http://issuu.com/restrella/docs/constitucion_del_ecuador; on Venezuela, see the Secree of 31 July 2008 establishing the Ley Orgánica de Seguridad y Soberanía Agroalimentaria at www.rnv.gov.ve/noticias/index.php?s $=$ b2c8b83055482f5ea1b0c8631a3dd973andact $=$ Attachandtype $=$ po standid=post-29-1217897618.ibf.

${ }^{97}$ See www.gmo-free-regions.org.

98 Land Oberösterreich and Austria v Commission [5 October 2005] CFI T-366/03; Land Oberösterreich and Austria v Commission [13 September 2007] ECJ C-439/05 P.

${ }^{99}$ See eg the statement by the Austrian minister of agriculture at www.news.at/articles/0910/15/235678/minister-berlakovich-eu-stirn-genmais-verbot-laender.

100 Special Eurobarometer, 'Europeans and Biotechnology in 2005: Patterns and Trends' (July 2006), 4243 at http://ec.europa.eu/public_opinion/archives/ebs/ebs_244b_en.pdf.

101 ibid, 46. Between 2002 and 2005, the 'trust surplus' - the difference between positive and negative assessments - for European regulation decreased from 48 to 42 , while that for national regulation increased from 27 to 33 .
} 
question of the appropriate sites of governance - and of their interplay - squarely back into the public debate. As we can observe from the sketch above, different visions clash here, and democratic depth and inclusiveness stand in tension with each other as well as with instrumental considerations stemming from the need for (relatively) harmonised rules in international trade. This is remarkable as an example of how this normative contestation feeds into and sustains the systemic pluralism of the different legal orders at play here. Claims for ultimate authority of the local, national, or European polities clash with each other and with those who want to situate that authority in a W'TO framework or in a broader 'international community'. In the GMO dispute, social and political contestation about the right collective - ultimately arguments about the scope and structure of a democratic polity - very visibly conditions the pluralist structure of governance.

\section{DISRUPTIVE PLURALISM?}

The story of the GMO dispute may be an instance of pluralism and also one of intense competition for authority by different collectives, but at first sight, it does not appear as an example of a particularly stable, or commendable, form of cooperation. In fact, it seems to be the opposite: the story of a breakdown of cooperation because of contestation and institutional fragmentation. A leading book on the issue then also bears the title When Cooperation Fails. ${ }^{102}$

Upon closer inspection, though, this characterisation appears as excessively gloomy, and it certainly is if we consider the broader picture of transnational food safety, environmental, and trade regulation. As I will try to show in this section, the contestation over GM food and feed signals the limits of what transnational regulation can aspire to, but it is also evidence of how much cooperation can be achieved in spite of deep-seated disagreement.

The outcome of the GMO dispute so far is naturally frustrating for proponents of GM products, and it often seems to simply reflect a noncooperative stance of the EU - and its success. As I have sketched above, early on, during the WTO proceedings, the EU has started again to process applications to import GM food and grow GM crops, but the number of decisions taken is still low, and every new one encounters much resistance from national governments. ${ }^{103}$ Moreover, member states maintain domestic bans on certain products and reject Commission efforts to remove them. Much of this dispute centres on whether

\footnotetext{
102 Pollack and Shaffer, n 2 above.

103 See eg J. Smith, 'EU Clashes on Authorizing Monsanto GM soybean' (19 November 2008) Reuters at http://uk.reuters.com/article/environmentNews/idUKTRE4AI71C20081119; Reuters, 'EU Approves Genetically Modified Soybean for Import' (4 December 2008) at

http://uk.reuters.com/article/environmentNews/idUKTRE4B33GO20081204; P.Harrison, 'EU Meeting on GM Maize Ends in Deadlock' (25 February 2009) Reuters at http://uk.reuters.com/article/behindTheScenes/idUKTRE51O57320090225.
} 
Monsanto's genetically modified MON810 corn can be cultivated. Approved by the EU already in 1998, it is subject to bans in several member states, and in February and March 2009, large majorities of member states voted down Commission proposals to lift these bans, despite positive assessments of the crop's safety by the European Food Safety Agency and other bodies.104 Emboldened by this political mood, in the spring of 2009, Luxemburg and Germany joined in with their own bans. ${ }^{105}$ And domestic courts have largely refused to interfere with those decisions. ${ }^{106}$

Yet there are also signs of cooperation and convergence, especially on a systemic level. EU courts, for instance, have adjusted their jurisprudence on precautionary measures in a way that comes very close to what the SPS Agreement requires. ${ }^{107}$ As Joanne Scott notes,

[t]he WTO Agreement may not have a direct effect in Community law, but it enjoys a significant, if still uncertain, capacity to influence strongly the interpretation of this body of law. ${ }^{108}$

This may not only be true for the area of GMOs, but for public health issues more broadly, ${ }^{109}$ and probably quite generally for other areas covered by WTO rules. The European courts may not always be explicit about it, and they may maintain their role as 'gatekeepers' at the door of EU law, but in substance, they have come to integrate WTO law into their jurisprudence almost as a matter of routine. ${ }^{110}$ This has led to a situation in which, in Francis Snyder's words, "[t]ogether, clear reference, transposition and consistent interpretation may prove nearly as effective as direct effect in integrating WTO law into EC law". ${ }^{111}$ As regards GMOs, the ECJ certainly has not been too cautious: it has not hesitated to find member state resistance in violation of EU law, and it has even imposed a substantial fine on France for its delayed implementation of Community legislation. ${ }^{112}$

\footnotetext{
104 P. Harrison, 'EU upholds Austria, Hungary Right to Ban GM Crops' (2 March 2009, Reuters at http://uk.reuters.com/article/environmentNews/idUKTRE5212OL20090302.

105 See ICTSD, 'Luxembourg to Ban GM Maize Cultivation' (3 April 2009) 9:6 Bridges Trade BioRes at http://ictsd.net/i/news/biores/44622/; Deutsche Welle, 'Germany to Ban US Biotech Giant's Genetically Modified Corn Strain' (14 April 2009) at www.dw-world.de/dw/article/0, $4176790,00 . h t m l$.

${ }^{106}$ See eg on France, Juge de Référés [19 March 2008] Conseil d'Etat No 313547 at www.legifrance.gouv.fr; on Germany, Verwaltungsgericht Braunschweig [4 May 2009] 2 B 111/09 at www.dbovg.niedersachsen.de/Index.asp?Doc=Aktenzeichen.

$107 \mathrm{~J}$. Scott, 'European Regulation of GMOs and the WTO' (2003) 9 Columbia Journal of European Law 213, 223, 228-229, 233; see also A. Alemanno, Trade in Food: Regulatory and Judicial Approaches in the EC and the WTO (London: Cameron May, 2007), 145.

108 Scott, n 107 above, 223.

109 See the (somewhat preliminary) assessment in M. Slotboom, 'Do Public Health Measures Receive Similar Treatment in European Community and World Trade Organization Law?' (2003) 37 Journal of World Trade 553, 594.

110 Snyder, n 66 above. See also Bronckers, n 66 above; A. Antoniadis, 'The European Union and WTO Law: A Nexus of Reactive, Coactive, and Proactive Approaches' (2007) 6 World Trade Review 45, 65-74.

111 Snyder, ibid, 362

112 Commission v France [9 December 2008] ECJ C-121/07.
} 
On the other hand, WTO jurisprudence has not been deaf to calls to give precaution greater weight in assessing the legality of SPS measures. Even if the outcomes of proceedings sometimes suggest the contrary, the Appellate Body has - at least in principle - opened doors in this direction, ${ }^{113}$ and the Panel in the Biotech case, as we have seen, has also refrained from rejecting the European approach outright. Not only did it decide on the narrowest basis possible, thus leaving a substantive assessment for future cases, but it also indicated to the EU how to pursue its approach in conformity with the SPS Agreement. As mentioned above, the Panel pointed out that if a risk assessment produced 'uncertainties or constraints' in its evaluation, restrictive measures by member states may be admissible. ${ }^{114}$ And in a clarifying letter, it reaffirmed that its findings did not restrain the freedom of the parties to act on new scientific evidence:

Particularly if the new or additional scientific evidence provides grounds for considering that the use or consumption of a product might constitute a risk to human health and/or the environment, a Member might need expeditiously to re-assess the risks to human health and/or the environment. ${ }^{115}$

Both the ECJ and the WTO Panel might thus insist on the autonomous interpretation of their respective bodies of law, but this principled stance does not hinder mutual awareness and consideration of the position and jurisprudence of each other - a form of 'muted dialogue', as one commentator has called it. ${ }^{116}$ After all, the legitimacy of both institutions is relatively fragile, and they depend on cooperative relations to avoid serious challenges. ${ }^{117}$ Yet in the GMO context, the full extent of dialogue and exchange only becomes visible when the view is broadened beyond the realm of judicial actors. One effect of the courts' reluctance to engage - by denying WTO law direct effect and by refraining from deciding upon substance - is to strengthen further the central role of political, regulatory institutions in the interaction between the different sites of governance.

EU regulation on GMOs has borne the stamp of WTO influence since at least the early 2000s - a time when the de facto moratorium on approvals of GM products was in full operation. The new legislation on the issue, adopted between 2001 and 2003,118 reflects the approach of the SPS Agreement in many key areas, especially in the formulation of the precautionary principle, the acceptance that restrictions on the import, cultivation, and sale of products need to be based on a

\footnotetext{
113 See Howse, n 13 above; Peel, n 11 above, 53-86.

114 See n 29 above.

115 Biotech, n 26 above at $[\mathrm{K}-2]$.

116 Bronckers, n 66 above.

117 See the account of the Biotech report in Pollack and Shaffer, $\mathrm{n} 2$ above, 220-224.

118 EC Directive No 2001/18/EC [12 March 2001], OJL 106/1 [17 April 2001]; Regulations (EC) No $1829 / 2003$ and 1830/2003 [22 September 2003], OJL 268/1 and 268/24 [18 October 2003].
} 
thorough, science-based risk assessment, and in its creation of a separate agency, EFSA, for that purpose. ${ }^{119}$

This reflects a broader trend towards convergence in risk regulation, triggered to a significant extent by SPS rules. European policy in this area before the Uruguay round was characterised by a parallelism of scientific and social/cultural concerns and by a mediated policy style that integrated decision-making on how much risk a certain product or process posed and what consequences to draw from that risk. ${ }^{120}$ The former issue was important to European negotiators on the SPS Agreement: they sought to include 'other concerns' than science as justification for trade-restrictive measures, partly in order to shield the European ban on hormonally-treated beef from WTO challenge. But the EC found itself with few allies and had to give in if negotiations were to continue - and it was keen on a successful conclusion because it sought to reduce obstacles to its own market access in other countries. It further did not want to see this issue (which after all had relatively low priority) threaten negotiations on other, more central aspects of the Uruguay Round. ${ }^{121}$ As a result, SPS rules came to require significant adjustment from Europe - adjustment at a time when the food safety scandals of the 1990s had substantially raised the political hurdles for liberalisation. The EU consequently tried to renegotiate the SPS Agreement, but was met with resistance by the US.122 Despite these problems with the agreement, however, we can observe far-reaching convergence on both principles and processes around the SPS approach. ${ }^{123}$ The EU has centred its new food safety regulation on scientific risk assessment as the key element, and it has also institutionally separated that risk assessment from the risk management that is performed by political bodies: while EFSA performs the former, the latter is undertaken in the Comitology system. ${ }^{124}$

Yet actual convergence goes much further than this and extends to detailed standards, as well. For example, since the 1990s, a large number of states have adopted the Hazard Analysis and Critical Control Point (HACCP) system in food safety regulation, which requires identification of critical control points and development of procedures for monitoring controls. ${ }^{125}$ The range of still existing differences between countries in this respect has been further narrowed by a template for HACCP that has been elaborated by the Codex Alimentarius

\footnotetext{
119 See Scott, n 107 above; see also Pollack and Shaffer, n 2 above, 237-245, 260-261.

${ }^{120}$ Skogstad, n 9 above, 488-492.

121 Skogstad, n 9 above, 492-494; Drezner, n 6 above, 162-163. But see also the somewhat different account in Büthe, n 9 above, 238-250.

122 Drezner, $\mathrm{n} 6$ above, 163.

${ }^{123}$ See D. Roberts, 'Preliminary Assessment of the Effects of the WTO Agreement on Sanitary and Phytosanitary Measures' (1998) 1 Journal of International Economic Law 377, 396-398; D. Roberts and L. Unnevehr, 'Resolving Trade Disputes Arising from Trends in Food Safety Regulation: The Role of the Multilateral Governance Framework' (2005) 4 World Trade Review 469, 470-475; see also Slotboom, n 109 above, 593-595.

${ }^{124}$ Skogstad, n 9 above, 497-501. It is the risk management process - a rather byzantine interplay between Commission and member states in an elaborate committee structure - that often produces outcomes with little relation to scientific findings, allowing member states to block approvals even if EFSA has not found a significant risk. See Pollack and Shaffer, n 2 above, 245-260.

125 Roberts and Unnevehr, n 123 above, 474.
} 
Commission. ${ }^{126}$ Codex has also developed a great number of other standards pertaining to both the process and substance of food safety regulation, ranging from guidelines for equivalence assessments between countries ${ }^{127}$, to a code of practice for the prevention and reduction of aflatoxin contamination in tree nuts ${ }^{128}$, to standards for oranges, dairy fat spreads, and camembert cheese altogether more than 3,000 standards. ${ }^{129}$ These are of course not binding, and member states can and do deviate from them, but both the weight assigned to them by the SPS Agreement and the commitment associated with consensus decision-making in Codex make them influential factors in domestic food safety regulation. ${ }^{130}$ They also often address controversial issues: for example, the abovementioned code of practice concerns an issue - aflatoxin levels - that had led to significant friction between the EU and its trading partners in the late 1990s.131 Since then, Codex has managed to adopt a range of guidelines on the issue. ${ }^{132}$

Cooperation and convergence are also facilitated within the WTO itself, where much of the work by far is not as fraught with friction as the widespread focus on the dispute settlement mechanism suggests. This is in large part due to the more informal and cooperative approach to problem-solving in the SPS Committee, where member states notify the Committee of their SPS measures, and others can lodge complaints against them. ${ }^{133}$ In this forum, many problems can be detected and raised early: from 1995 to 2008, more than 7,500 SPS measures were notified to the Committee, and 277 'specific trade concerns' were raised. ${ }^{134}$ A significant number of these concerns - about one third - was wholly or partially resolved, through broader information, better mutual understanding,

\footnotetext{
126 See Recommended International Code of Practice - General Principles of Food Hygiene (1969, last revised 2003) Codex Doc CAC/RCP 1 at www.codexalimentarius.net/web/more_info.jsp?id_sta=23; see Roberts and Unnevehr, n 123 above, 492.

${ }^{127}$ Guidelines on the Judgement of Equivalence of Sanitary Measures Associated with Food Inspection and Certification Systems (2003, revised 2008) Codex Doc CAC/GL 53 at www.codexalimentarius.net/web/more_info.jsp?id_sta=10047.

${ }^{128}$ Code of Practice for the Prevention and Reduction of Aflatoxin Contamination in Tree Nuts (2005) Codex Doc CAC/RCP 59 at www.codexalimentarius.net/web/more_info.jsp?id_sta=10221.

129 Standards are available at www.codexalimentarius.net/web/standard_list.do?lang=en. On the activity of the Codex, see F. Veggeland and S.O. Borgen, Negotiating International Food Standards: The World Trade Organization's Impact on the Codex Alimentarius Commission' (2005) 18 Governance 675, 676; see also Pollack and Shaffer, $\mathrm{n} 2$ above, 164.

130 See the assessment of the importance of Codex standards by governments in Report of the Evaluation of the Codex Alimentarius and other FAO and WHO Food Standards Work (15 November 2002) at www.who.int/foodsafety/codex/eval_report/en/index.html, paras 56-59. Other indicators of their importance is the level of resources invested in them and the degree of participation in meetings. Participation has increased significantly over the last twenty years and has yet again reached record levels in 2008; see Veggeland and Borgen, n 129 above, 687-689; Report of the U.S. Delegate (31st Session of the Codex Alimentarius Commission, 2008) at www.fsis.usda.gov/codex_alimentarius/Delegate_Report_31CAC/index.asp.

131 See Roberts and Unnevehr, n 123 above, 486-487.

132 See also the codes of practice on peanuts: (2004) Codex Doc CAC/RCP 55 at www.codexalimentarius.net/web/more_info.jsp?id_sta=10084) and dried figs: (2008) Codex Doc CAC/RCP 65 at www.codexalimentarius.net/web/more_info.jsp?id_sta=11025).

133 See Scott, n 10 above, ch 2.

134 Review of the Operation and Implementation of the SPS Agreement (6 February 2009) WTO Doc G/SPS/GEN/887/Rev.1, paras 25, 66.
} 
capacity-building, and/or the adjustment or withdrawal of the measures in question. ${ }^{135}$ Moreover, cooperation in the Committee helps to concretise rules and align normative expectations so that member states can anticipate, avoid, or solve potential problems early on. ${ }^{136}$ For example, EU safeguard measures restricting imports from a number of African countries following a cholera outbreak were questioned in the SPS Committee by Tanzania. Partly due to interventions by the observer representative of the $\mathrm{WHO}$, the EU recognised that the actual risk of cholera transmission from food imports was very low and therefore withdrew the measures. The debate settled the particular dispute, but it also helped shape member states' views on the appropriate standards for the matter along the lines of WHO guidance. ${ }^{137}$ In another example, a dispute over HACCP requirements by the Philippines, brought up by Canada, led to extensive debate among Committee members and helped them to elaborate a common approach to what HACCP did, and should, imply - beyond the solution of the particular dispute in which the Philippines deferred implementation of its policy indefinitely. ${ }^{138}$

These examples signal a relatively high degree of cooperation and policy convergence in an area that has become heavily politicised in the last twenty years. This is noteworthy in and of itself, but it should of course not conceal the limits of cooperation. Regarding those issues where positions are far apart, heavily entrenched, and enjoy considerable global support on both sides, cooperative successes have often been elusive. This is true in the Codex Commission for the debates on the role of precaution and of 'other legitimate factors' in food safety risk management in general. On both issues, Codex has managed to produce compromise documents, but they are very vague and bracket, rather than resolve, the conflict. ${ }^{139}$ The most intransigent problems, however, are related to biotechnology in particular: on issues such as labelling and traceability in GM products, common ground could not be found within Codex. ${ }^{140}$ This does not imply, though, that no progress has been achieved on GMO-related issues at all. ${ }^{141}$ In 2003, Codex managed to agree on Principles and Guidelines on Foods Derived from Biotechnology, which contains three sets of norms on risk assessment and food safety analysis for GM foods. ${ }^{142}$ The task force that had prepared these documents

\footnotetext{
135 Overview of all the Specific Trade Concerns (5 February 2009) WTO Doc. G/SPS/GEN/204/Rev.9, paras 8, 10; Specific Trade Concerns (6 February 2009) G/SPS/GEN/204/Rev.9/Add.3. As this report by the WTO Secretariat notes, some solved cases may not have been reported. See also Scott, n 10 above, 50-60; Roberts and Unnevehr, n 123 above, 480-482, 493.

136 Scott, n 10 above, 50-60, 69-74. For a broader analysis of functions of information exchange and norm elaboration in WTO non-judicial governance, see A. Lang and J. Scott, 'The Hidden World of WTO Governance' (2009) 20 European Journal of International Law 575.

137 Scott, n 10 above, 53-54.

138 ibid, 54-55.

139 See S. Poli, 'The European Community and the Adoption of International Food Standards within the Codex Alimentarius Commission' (2004) 10 European Law Journal 613, 619-625; Veggeland and Borgen, n 129 above, 694-697.

140 See Poli, n 139 above, 626-629; Pollack and Shaffer, n 2 above, 170-171.

141 See Pollack and Shaffer, ibid, 166-168.

142 Principles for the Risk Analysis of Foods Derived from Modern Biotechnology (2003, revised 2008)

Codex Doc CAC/GL 44; Guideline for the Conduct of Food Safety Assessment of Foods Derived from
} 
was judged a success, ${ }^{143}$ had its mandate extended, and managed to agree upon a number of further documents, especially regarding risk assessments in particular areas. ${ }^{144}$

The overall picture of global regulatory cooperation on food safety and related SPS matters is thus not as bleak as it is sometimes made out to be: although the area may be characterised as one of fundamentally 'contested governance', 145 cooperation is routine and both broad and relatively deep, and even on GMO issues, we can observe significant regulatory successes. Yet there are limits: as we have seen, efforts at cooperation have led to unsatisfactory results, or have failed outright, on issues of a particularly high domestic salience. ${ }^{146}$ And they certainly have been less successful in matters with entrenched positions of important societal actors than in those arising anew. ${ }^{147}$

\section{CONCLUSION}

Are these limits of cooperation the product of the pluralist governance structure that I have described above? Pollack and Shaffer suggest as much when they point to the difficulties that arise from the competition between, and forum-shopping for, the multiple regulatory sites at play. ${ }^{148}$ Yet they are quick to acknowledge that this multiplicity itself is not so much the cause as the effect of "underlying differences among states and social constituencies in a diverse, pluralist world". 149 Could then a more tightly integrated, hierarchically organised, 'constitutionalist' structure have helped to overcome the difficulties of cooperation? In a formal sense, yes: it might have assigned decision-making rights to particular institutions, thus potentially breaking the deadlock that has arisen in consensual settings, such as Codex. Yet there are reasons to doubt that such powers would eventually have made a significant difference. Even those institutions that enjoy unilateral decision-making powers have been hesitant to exercise them: the WTO Panel in

Recombinant-DNA Plants (2003, revised 2008) CAC/GL 45; Guideline for the Conduct of Food Safety Assessment of Foods Produced Using Recombiant-DNA Microorganisms (2003) CAC/GL 46. All of the above are available at

www.codexalimentarius.net/web/standard_list.do?lang=en. See also Ostrovsky, n 14 above, 818-821.

143 Report of the Evaluation, n 130 above, para 69, box 2.

144 See Report of the U.S. Delegate (7th Session of the Codex ad hoc Intergovernmental Task Force on Foods Derived From Biotechnology, Chiba, Japan, September 24-28, 2007) at www.fsis.usda.gov/Regulations_and_Policies/Delegate_Report_7FBT/index.asp.

${ }^{145}$ C. Ansell and D. Vogel, 'The Contested Governance of European Food Safety Regulation', in Ansell and Vogel, $n 4$ above, 3-32, 10-12.

146 See Pollack and Shaffer, n 2 above, 280-285; see also (on the beef hormones dispute) S. Princen, 'EC Compliance with WTO Law: the Interplay of Law and Politics' (2004) 15 European Journal of International Law 555, 570.

147 Princen, n 146 above, 572-573; A.R. Young and P. Holmes, 'Protection or Protectionism? EU Food Safety and the WTO', in Ansell and Vogel, n 4 above, 281-305, 298, 303.

148 Pollack and Shaffer, n 2 above, 175, 284-286.

149 ibid, 176. 
Biotech has refrained from any but the narrowest findings against the EU, and the EU Commission has been very cautious in pressing GMO issues on member states even when it had the formal basis to do so. In both cases, this hesitation is likely linked to concerns about legitimacy: those institutions would overstretch their normative resources and would thus undermine their position in the longterm. 150

This raises broader questions about the societal factors that condition governance structures. The structure underlying the regulatory conflict over GMO products has been likened to a collaboration game of a battle of the sexes type one in which cooperation would be pareto-improving, but where distributive costs are so high as to render agreement impossible. ${ }^{151}$ Framing the problem in these terms, however, suggests solutions that are actually unavailable, for normally distributive costs could be overcome by side-payments if the eventual outcome remained pareto-optimal. This would likely be the case here: one could well imagine the US paying off the EU for some of the adjustment costs it would bear when switching to a more GMO-friendly regime. However, this has not happened, and it is also unlikely to happen because significant constituencies within the EU regard the issue as one of culture and values - as an issue with an absolute baseline, not to be traded off against other, diffuse gains. This points to the nonexchangeable character of the goods involved here, and it suggests that the costs of cooperation simply outweigh its benefits, making a stable equilibrium impossible to achieve. ${ }^{152}$

Moreover, as we have seen, because the issue has such political salience, it is also seen by many as one that is not amenable to technical, delegated decisionmaking, but as one that is properly subject to democratic determination in the local or (at most) national realm. On GMOs, therefore, we face an entrenchment not only of a substantive, but also of a procedural position - a position on the relevant polity. Creating a more 'constitutionalist' legal and governance structure one that assigns decision-making rights at a higher level and thus allows for effective coordination - may force actors to cooperate, but it would conflict with the views of important sections of the population and would likely create significant resistance, potentially threatening the institutional structure itself. In this situation, a pluralist order may not only be normatively more attractive, it might also be the more prudent option. Leaving hierarchies and issues of principle undecided may allow space for pragmatic solutions on issues that are less fraught and might provide a safety valve when one or the other site of governance overreaches.

\footnotetext{
150 On the WTO, see n 117 above; on the need for a mediative policy style in the EU, see G. Skogstad, 'Regulating Food Safety Risks in the European Union: A Comparative Perspective', in Ansell and Vogel, n 4 above, 213-236, 219-220.

151 Pollack and Shaffer, n 2 above, 117-130, 285.

152 See also Drezner, n 6 above, 210.
} 